\title{
Effects of Daily Harvest Time on Postharvest Longevity, Water Relations, and Carbohydrate Status of Selected Specialty Cut Flowers
}

\author{
Iftikhar Ahmad ${ }^{1,4}$ \\ Department of Horticultural Science, North Carolina State University, 158 \\ Kilgore Hall, 2721 Founders Drive, Raleigh, NC 27695-7609; and the Institute of \\ Horticultural Sciences, University of Agriculture, Faisalabad-38040, Pakistan
}

John M. Dole ${ }^{2}$ and Frank A. Blazich ${ }^{3}$

Department of Horticultural Science, North Carolina State University, Raleigh, NC 27695-7609

Additional index words. cut flowers, Eustoma grandiflorum, fructose, glucose, sucrose, Tagetes erecta, Zinnia elegans

Abstract. Effects of harvest time (morning, noon, or afternoon) on water uptake, fresh weight changes, termination symptoms, leaf relative water content (LRWC), carbohydrate status, and vase life of cut 'ABC Purple' lisianthus (Eustoma grandiflorum Salisb.), 'Double Eagle' African Gold Coin Series marigold (Tagetes erecta L.), and 'Deep Red' Benary's Giant Series zinnia (Zinnia elegans Jacq.) were studied. For stems of lisianthus harvested and then stored in the dark with the basal ends in water for 2 weeks at $3 \pm 1^{\circ} \mathrm{C}$, those harvested at noon (1200 $\mathrm{HR}$ to $1300 \mathrm{HR}$ ) or in the afternoon (1700 $\mathrm{HR}$ to $1800 \mathrm{HR}) \mathrm{had}$ longer vase life compared with stems harvested in the morning (0700 $\mathrm{HR}$ to $0800 \mathrm{HR})$. However, stems of lisianthus evaluated without storage had no differences in vase life. Stems of marigold harvested in the afternoon had longer vase life than morning- or noonharvested stems. Time of harvest had no effect on cut flower longevity of zinnia. However, vase life was considerably shorter for stems of all species when tested after 2 weeks storage compared with freshly harvested stems. Stems of zinnia harvested at noon had lower LRWC than morning- or afternoon-harvested stems. Marigold stems harvested in the afternoon and evaluated without storage had lowest LRWC on Day 7 of vase life. Harvest time or storage did not influence LRWC of lisianthus. Stems of marigold and lisianthus harvested at noon or in the afternoon had higher levels of carbohydrates compared with morning-harvested stems, whereas freshly harvested stems had higher concentrations of glucose and sucrose, which decreased during storage or the vase period. Sucrose concentrations varied more significantly among various tissues than other sugars presumably as a result of translocation during vase life. In summary, carbohydrate status of stems harvested at different times of the day varied greatly and affected postharvest longevity of cut marigold and lisianthus, but not zinnia.

Many post-production factors affect vase life of cut flowers including developmental stage at harvest, temperature during the vase

Received for publication 13 Nov. 2013. Accepted for publication 27 Dec. 2013.

This research was funded in part by the North Carolina Agricultural Research Service (NCARS), Raleigh, NC.

Use of trade names in this publication does not imply endorsement by the NCARS of products named nor criticism of similar ones not mentioned. We thank John D. Williamson for critically reviewing the manuscript and Weiwen Guo for technical assistance with carbohydrate analysis. We are also grateful to the Endowment Fund Secretariat, University of Agriculture, Faisalabad, Pakistan, for financial support of the senior author.

${ }^{1}$ Postdoc Scholar.

${ }^{2}$ Professor and Head.

${ }^{3}$ Alumni Distinguished Graduate Professor Emeritus. ${ }^{4}$ To whom reprint requests should be addressed; e-mail iftikharahmadhashmi@gmail.com,iahmad3@ ncsu.edu. period, water loss, and various aspects of the vase solution such as sucrose levels, microbial populations, $\mathrm{pH}$, electrical conductivity (EC), and overall water quality (Sacalis, 1993). To maintain flower quality, studies have focused on storage (Ahmad et al., 2012; Çelikel and Reid, 2002; Jones et al., 2004), floral preservatives (Doi and Reid, 1995; Elhindi, 2012; Gast, 1997), or use of ethylene inhibitors, e.g., silver thiosulfate and 1methylcyclopropene (Blankenship and Dole, 2003; Chamani et al., 2005), nano-silver (Kim et al., 2005; Liu et al., 2012), and other commercial antiethylene agents (Staby et al., 1993). However, postharvest longevity of cut flowers is also affected by a variety of both preharvest (e.g., harvest season, solar radiation, temperature, relative humidity, water, and mineral nutrient stress) (Halevy and Mayak, 1979; Reid and Jiang, 2012; Slootweg, 2005) and postharvest (e.g., harvest stage, harvest procedures, ethylene, vase water quality, preservatives, storage method and duration, etc.) factors (Halevy and Mayak, 1981; Marissen and Benninga, 2001; van Doorn, 2012). In addition to the aforementioned factors, the time of the day when stems are harvested may be a potentially important consideration (Clarkson et al., 2005; Hasperué et al., 2011; Rapaka et al., 2007).

Generally, stems are harvested by growers in the morning allowing more time for processing and marketing and to avoid field heat, which preserves quality and minimizes transpiration and thereby desiccation. However, for many species, morning harvest may not be the proper time because many plant physiological processes change diurnally and can affect postharvest longevity of cut stems. For instance, diurnal variations in ascorbic acid levels of spinach (Spinacea oleracea L.) (Kiyota et al., 2006) and chlorophyll precursors in bean (Phaseolus vulgaris L.) (ArgyroudiAkoyunoglou and Prombona, 1996) have been reported. However, the most pronounced effect of diurnal fluctuations has been observed on carbohydrate metabolism in plants (Hasperué et al., 2011). Changes in solar radiation greatly affect endogenous carbohydrate reserves, which accumulate during the day and are remobilized by the end of the dark period (Sicher et al., 1984).

Harvesting later in the day compared with morning harvesting increased shelf life considerably for leaves of basil (Ocimum basilicum L.) (Lange and Cameron, 1994), baby salad [Eruca vesicaria (L.) ssp. Sativa (Mill.)] Thell. (Clarkson et al., 2005), and unrooted shoot-tip cuttings of lantana (Lantana comara L.) (Rapaka et al., 2007). These variations in shelf life were attributed to varying carbohydrate levels and diurnal changes in plant metabolic processes.

Genotype and environmental conditions can also impact postharvest longevity. Cultivars of lettuce (Lactuca sativa L.) harvested at different times during the day have varying postharvest quality (Moccia et al., 1998). Butterhead lettuce had the best quality when harvested later in the day, whereas Latin-type lettuce had the best quality when harvested in early morning. Moreover, fluctuations in carbohydrate levels of field-grown crisphead lettuce have been observed between morning and afternoon harvests (Forney and Austin, 1988). Crisphead lettuce harvested in the afternoon had higher sucrose than morning harvests, whereas glucose and fructose were greater in morning harvests. Soluble sugars like sucrose act as signaling molecules for plants under stress and move between cells causing fluctuations in sugar concentrations during senescence (Chuang and Chang, 2013). Moreover, sucrose application reduced ethylene responsiveness in florets of broccoli (Brassica oleracea L.) and carnation (Dianthus caryophyllus L.) flowers (Nishikawa et al., 2005; Verlinden and Garcia, 2004). These diurnal plant carbohydrate changes can greatly affect postharvest longevity of cut flowers. However, limited information is available on the effects of time of harvest on extending postharvest performance (vase life) of particular ornamental crops. Therefore, 
the following study was conducted to define time of harvest requirements for extending longevity and maintaining quality with or without storage of three popular specialty cut flowers. Storage of cut stems was included in the studies to determine the physiological changes in different sugars taking place during storage and the vase period. Moreover, storage of cut flowers is an essential practice used to extend availability and prolong freshness of cut flowers; therefore, it is necessary to quantify the metabolism of sugars during storage.

The objectives of the present investigation were to 1) study effects of harvesting at different times of the day on water uptake, changes in fresh weight, termination symptoms, LRWC, carbohydrates status, and vase life of cut 'ABC Purple' lisianthus (Eustoma grandiflorum), 'Double Eagle' African Gold Coin Series marigold (Tagetes erecta), a major flower species in the Indo-Pak subcontinent, and 'Deep Red' Benary's Giant Series zinnia (Zinnia elegans), one of the top three field specialty cut species in the United States; and 2) assess possible mechanisms affecting vase life of fresh or stored cut stems by evaluating changes in water relations and carbohydrate levels. It was hypothesized that harvesting stems in the morning may reduce vase life of lisianthus, marigold, and zinnia.

\section{Materials and Methods}

Research was conducted at the Postharvest Laboratory, Department of Horticultural Science, North Carolina State University, Raleigh, and the Horticulture Field Laboratory, Raleigh. In Summer 2011, lisianthus, marigold, and zinnia were field-grown using standard commercial practices. For each species, stems were harvested at various times on the same day, morning ( $0700 \mathrm{HR}$ to $0800 \mathrm{HR}$ ), noon (1200 HR to $1300 \mathrm{HR}$ ), or afternoon
(1700 HR to $1800 \mathrm{HR}$ ), placed in buckets containing tap water, and transported to the postharvest laboratory within $1 \mathrm{~h}$ of harvest. On the days of harvest, maximum, minimum, and average temperatures were $32.9,20.7$, and $25.4{ }^{\circ} \mathrm{C}$ for lisianthus and $33.1,20.2$, and $26.4^{\circ} \mathrm{C}$ for marigold and zinnia, respectively. Average photosynthetically active radiation was $625.7 \mu \mathrm{mol} \cdot \mathrm{m}^{-2} \cdot \mathrm{s}^{-1}$ for lisianthus and $557.3 \mu \mathrm{mol} \cdot \mathrm{m}^{-2} \cdot \mathrm{s}^{-1}$ for marigold and zinnia. Time for sunrise and sunset were $0604 \mathrm{HR}$ and $0834 \mathrm{HR}$, respectively, for lisianthus, and $0558 \mathrm{HR}$ and $2033 \mathrm{HR}$ for marigold and zinnia, whereas daylength and solar noon time were $14 \mathrm{~h} 30 \mathrm{~min}$ and $1319 \mathrm{HR}$, respectively, for lisianthus or $14 \mathrm{~h} 35 \mathrm{~min}$ and $1316 \mathrm{HR}$ for marigold and zinnia. Harvested stems were sorted according to stage of development, stem caliper, flower head size, and number of buds per stem (lisianthus only) and arranged into six uniform groups of 25 stems having similar characteristics. Stems of lisianthus had one or two almost fully colored flowers with other semiopen or closed buds, whereas marigold and zinnia flowers were mature with $\approx 50 \%$ opened petals. Stems were recut from the bases to lengths of $30 \mathrm{~cm}$, labeled, and either placed into vases containing $300 \mathrm{~mL}$ tap water ( $\mathrm{pH} 6.2$, EC $\left.0.29 \mathrm{dS} \cdot \mathrm{m}^{-1}\right)$ or placed in buckets containing tap water and stored for 2 weeks in the dark at $3 \pm 1{ }^{\circ} \mathrm{C}$ followed by placement in vases for evaluation. Cut stems were stored to determine the metabolism of sugars during that commonly used practice for extending availability and vase life. Each treatment had five replications of three stems per vase. Ten additional stems per treatment were used for measuring LRWC and carbohydrate levels. Vases with cut stems were arranged on benches in completely randomized designs in a postharvest evaluation room. The room was maintained at $20 \pm 2{ }^{\circ} \mathrm{C}$ with $40 \%$ to $60 \%$ relative humidity and a 12 -h photoperiod provided by cool-white fluorescent lamps. The lamps provided a photosynthetic photon flux of $\approx 20 \mu \mathrm{mol} \cdot \mathrm{m}^{-2} \cdot \mathrm{s}^{-1}$ as measured at bench level with a 1078 QMSW Quantum meter (Apogee Instruments, Inc., Logan, UT).

Data collected included water uptake (measured from all vases when first stem in the entire experiment was ended); initial fresh weight (measured before placing stems in vases) and termination fresh and dry weight (dried at $70{ }^{\circ} \mathrm{C}$ for $72 \mathrm{~h}$ ) of an initially designated one stem per vase; $\mathrm{pH}$ and EC changes (for each vase); LRWC (Day 0 or 7 after beginning of vase life determination); carbohydrate contents (mg. $\mathrm{g}^{-1}$ fresh weight) of stem, leaf, and petal tissues (Day 0 or 7 after beginning of vase life determination); symptoms of termination for all stems; and vase life. Vase life was determined as the duration from placement of stems in vases to the time when individual stems of each species had developed one or more of the termination symptoms on $50 \%$ or greater of the stem. LRWC was determined following procedures of Smart and Bingham (1974) using the formula: LRWC $(\%)=($ fresh weight dry weight)/(turgid fresh weight - dry weight) $\times 100$. For measurements of LRWC, samples were collected at harvest, packed in sealed polyethylene bags, and stored in a cooler with ice until measurements were taken. Turgid fresh weight was recorded after storage of samples in ice cold water and held in a refrigerator for $4 \mathrm{~h}$. When recording turgid fresh weight, leaf samples were gently blotted with tissue paper to remove extra moisture and weighed. Afterward, the samples were placed in an oven at $70{ }^{\circ} \mathrm{C}$ for $72 \mathrm{~h}$ for dry weight determination. Symptoms of termination were recorded as present or not present and included petal browning, fading, necrosis, or wilting; stem bent neck and/or leaf wilting for lisianthus; petal browning, drying, shedding, head collapse, or wilting; stem bent neck or adventitious rooting and/or

Table 1. Effect of storage duration and harvest time on vase life, water uptake, number of flowers opened, and termination symptoms (petal fading, bent neck, or leaf wilting) of 'ABC Purple' lisianthus.'

\begin{tabular}{|c|c|c|c|c|c|c|c|}
\hline \multicolumn{2}{|c|}{ Treatments } & \multirow[b]{2}{*}{ Vase life $(d)$} & \multirow[b]{2}{*}{$\begin{array}{c}\text { Water } \\
\text { uptake }(\mathrm{mL})\end{array}$} & \multirow[b]{2}{*}{$\begin{array}{c}\text { Number of } \\
\text { flowers opened }^{y}\end{array}$} & \multicolumn{3}{|c|}{ Termination symptoms $\mathrm{s}^{\mathrm{x}}$} \\
\hline $\begin{array}{l}\text { Storage duration } \\
\text { (weeks) }\end{array}$ & Harvest time & & & & Petal fading (\%) & Bent neck (\%) & Leaf wilting (\%) \\
\hline \multirow[t]{2}{*}{$\overline{0}$} & $0700 \mathrm{HR}$ to $0800 \mathrm{HR}$ & $10.7 \mathrm{a}^{\mathrm{w}}$ & $20.2 \mathrm{~b}$ & $0.8 \mathrm{ab}$ & $87 \mathrm{a}$ & $40 \mathrm{c}$ & $13 \mathrm{ab}$ \\
\hline & $1200 \mathrm{HR}$ to $1300 \mathrm{HR}$ & $10.7 \mathrm{a}$ & $19.4 \mathrm{~b}$ & $1.1 \mathrm{a}$ & $73 \mathrm{ab}$ & $100 \mathrm{a}$ & $20 \mathrm{ab}$ \\
\hline \multirow[t]{2}{*}{2} & $0700 \mathrm{HR}$ to $0800 \mathrm{HR}$ & $4.3 \mathrm{c}$ & $18.8 \mathrm{~b}$ & $0.3 \mathrm{c}$ & $67 \mathrm{ab}$ & $80 \mathrm{ab}$ & $40 \mathrm{a}$ \\
\hline & $1200 \mathrm{HR}$ to $1300 \mathrm{HR}$ & $5.9 \mathrm{~b}$ & $18.8 \mathrm{~b}$ & $0.4 \mathrm{bc}$ & $27 \mathrm{c}$ & $53 \mathrm{bc}$ & $40 \mathrm{a}$ \\
\hline \multicolumn{8}{|l|}{ Significance $^{\mathrm{v}}$} \\
\hline & Overall & $<0.0001$ & 0.0119 & 0.0012 & 0.0004 & 0.0011 & NS \\
\hline & Storage (S) & $<0.0001$ & 0.0114 & 0.0005 & $<0.0001$ & NS & 0.0086 \\
\hline & Harvest time $(\mathrm{H})$ & 0.0011 & NS & NS & 0.0497 & NS & NS \\
\hline & $\mathrm{S} \times \mathrm{H}$ & 0.0240 & NS & NS & NS & 0.0004 & NS \\
\hline
\end{tabular}

${ }^{\text {z }}$ Stems were harvested at three different times of the day ( $0700 \mathrm{HR}$ to $0800 \mathrm{HR}, 1200 \mathrm{HR}$ to $1300 \mathrm{HR}$, or $1700 \mathrm{HR}$ to $1800 \mathrm{HR}$ ), placed in buckets containing tap water, transported to the laboratory within $1 \mathrm{~h}$ of harvest, sorted on the basis of stage of development, stem caliper, and number of opened flowers, labeled, and either stored in the dark at $3 \pm 1{ }^{\circ} \mathrm{C}$ for 2 weeks in buckets containing tap water or placed in a postharvest evaluation laboratory in vases containing $300 \mathrm{~mL}$ tap water with three stems per vase. Data for water uptake represent means of five vases, whereas all other data represent means of 15 stems with three stems per vase.

y Number of opened flowers at termination minus number of opened flowers at harvest.

xPercentage of stems exhibiting symptoms.

${ }^{\text {w}}$ Mean separation within columns by Fisher's least significant difference at $P \leq 0.05$.

${ }^{\mathrm{v}} P$ values were obtained using General Linear Models procedures of SAS (Version 9.1; SAS Inst., Inc., Cary, NC).

NS $=$ Nonsignificant at $P>0.05$. 
leaf wilting for marigold; and petal blackening/necrosis, drying, fading, or wilting, stem collapse, and/or leaf wilting for zinnia. The condition was recorded as present if it occurred on at least one petal, leaf, or bud and stems were ended when they developed one or more of the aforementioned symptoms. The experiments with marigold and zinnia were also repeated for confirmation of results.

For carbohydrate determinations, three additional stems per treatment were used on Day 0 or 7 of vase life. The stems that had been treated as described and hydrated in tap water for $2 \mathrm{~h}$ were sectioned into stem, leaves, and petals and stored at $-80{ }^{\circ} \mathrm{C}$ for later carbohydrate extraction and analysis. Approximately $500 \mathrm{mg}$ of each sample was extracted in $3 \mathrm{~mL} 80 \%$ ethanol (EtOH). Samples were vortexed to suspend the tissues, placed in a sonicating water bath, and heated at $80{ }^{\circ} \mathrm{C}$ for $5 \mathrm{~min}$. Heated samples were centrifuged at $3000 \mathrm{~g}_{\mathrm{n}}$ for $5 \mathrm{~min}$ at $4{ }^{\circ} \mathrm{C}$. The supernatant was removed to a new



Day 0

Day 7

Fig. 1. Effect of daily harvest time ( $0700 \mathrm{HR}$ to $0800 \mathrm{HR}, 1200 \mathrm{HR}$ to $1300 \mathrm{HR}$, or $1700 \mathrm{HR}$ to $1800 \mathrm{HR}$ ), storage duration (no storage or 2 weeks), and day of sampling after beginning of vase life determination (Day 0 or 7) on glucose (A-B), sucrose (C-D), and fructose (E-F) levels in stem, leaf, and petal tissues of "ABC Purple' lisianthus. Each bar is a mean of three observations. A bar without an asterisk indicates nonsignificant and *, **, or *** indicate significant at $P \leq 0.05$, 0.01 , or 0.001 , respectively. 
labeled tube, and the pellet was resuspended in $3 \mathrm{~mL} 80 \% \mathrm{EtOH}$, vortexed, sonicated, heated at $80^{\circ} \mathrm{C}$ in a water bath, centrifuged, and the supernatant recovered two more times. Combined supernatants $(9 \mathrm{~mL})$ were evaporated in a rotary evaporator (Integrated SpeedVac concentrator, ISS110; Savant Instruments, Inc., Holbrook, NY) and stored at $-20{ }^{\circ} \mathrm{C}$. For analysis, dried samples were reconstituted in $1 \mathrm{~mL}$ distilled water and centrifuged to remove remaining particulate matter. Aliquots $(600 \mu \mathrm{L})$ of the supernatant were dispensed into high-performance liquid chromatography (HPLC) vials. Carbohydrates were separated by HPLC (LaChrom

Table 2. Significance level of harvest time, storage duration, and day of sampling on carbohydrates contents of stems, leaves, and petals or total sugars of 'ABC Purple' lisianthus, 'Double Eagle' African Gold Coin Series marigold, and ‘Deep Red' Benary's Giant Series zinnia.'



${ }^{\mathrm{z}}$ Stems were harvested at three different times of the day ( $0700 \mathrm{HR}$ to $0800 \mathrm{HR}, 1200 \mathrm{HR}$ to $1300 \mathrm{HR}$, or $1700 \mathrm{HR}$ to $\left.1800 \mathrm{HR}\right)$, placed in buckets containing tap water, transported to the laboratory within $1 \mathrm{~h}$ of harvest, sorted on the basis of stem caliper, stage of development, and number of opened flowers (lisianthus only), labeled, and either stored in the dark at $3 \pm 1{ }^{\circ} \mathrm{C}$ for 2 weeks in buckets containing tap water or placed in a postharvest evaluation laboratory in vases containing $300 \mathrm{~mL}$ tap water with three stems per vase. Samples were prepared on Day 0 or 7 of vase life, extracted with $80 \%$ ethanol, and analyzed by high-performance liquid chromatography. $P$ values were obtained using General Linear Models procedures of SAS (Version 9.1; SAS Inst., Inc., Cary, NC). NS $=$ Nonsignificant at $P>0.05$.

Table 3. Effect of storage duration and harvest time on vase life, fresh weight change, water uptake, and termination symptoms (petal wilting, petal blackening, head collapse, bent neck, or stem rooting) of 'Double Eagle' African Gold Coin Series marigold. ${ }^{\text {' }}$

\begin{tabular}{|c|c|c|c|c|c|c|c|c|c|}
\hline \multicolumn{2}{|c|}{ Treatments } & \multirow[b]{2}{*}{$\begin{array}{l}\text { Vase } \\
\text { life (d) }\end{array}$} & \multirow[b]{2}{*}{$\begin{array}{l}\text { Fresh wt } \\
\text { change }^{\mathrm{y}}(\mathrm{g})\end{array}$} & \multirow[b]{2}{*}{$\begin{array}{c}\text { Water } \\
\text { uptake }(\mathrm{mL})\end{array}$} & \multicolumn{5}{|c|}{ Termination symptoms $^{\mathrm{x}}$} \\
\hline $\begin{array}{l}\text { Storage duration } \\
\text { (weeks) }\end{array}$ & Harvest time & & & & $\begin{array}{c}\text { Petal } \\
\text { wilting (\%) }\end{array}$ & $\begin{array}{c}\text { Petal } \\
\text { blackening }(\%)\end{array}$ & $\begin{array}{c}\text { Head } \\
\text { collapse }(\%)\end{array}$ & $\begin{array}{c}\text { Bent } \\
\text { neck }(\%)\end{array}$ & $\begin{array}{c}\text { Stem } \\
\text { rooting (\%) }\end{array}$ \\
\hline \multirow[t]{2}{*}{$\overline{0}$} & $0700 \mathrm{HR}$ to $0800 \mathrm{HR}$ & $9.5 \mathrm{~b}^{\mathrm{w}}$ & $1.6 \mathrm{a}$ & $118.8 \mathrm{a}$ & $73 \mathrm{~b}$ & $33 \mathrm{bc}$ & $60 \mathrm{a}$ & $0 \mathrm{~b}$ & $47 \mathrm{a}$ \\
\hline & $1700 \mathrm{HR}$ to $1800 \mathrm{HR}$ & $12.3 \mathrm{a}$ & $1.3 \mathrm{a}$ & $108.2 \mathrm{~b}$ & $86 \mathrm{ab}$ & $67 \mathrm{ab}$ & $13 \mathrm{~b}$ & $0 \mathrm{~b}$ & $33 \mathrm{a}$ \\
\hline \multirow[t]{2}{*}{2} & $0700 \mathrm{HR}$ to $0800 \mathrm{HR}$ & $4.2 \mathrm{~d}$ & $-6.4 b$ & $21.2 \mathrm{c}$ & $100 \mathrm{a}$ & $53 \mathrm{abc}$ & $0 \mathrm{~b}$ & $33 \mathrm{a}$ & $0 \mathrm{~b}$ \\
\hline & $1200 \mathrm{HR}$ to $1300 \mathrm{HR}$ & $5.3 \mathrm{~d}$ & $-5.5 \mathrm{~b}$ & $25.0 \mathrm{c}$ & $100 \mathrm{a}$ & $73 \mathrm{a}$ & $7 \mathrm{~b}$ & $7 \mathrm{~b}$ & $0 \mathrm{~b}$ \\
\hline \multicolumn{10}{|l|}{ Significance $^{\mathrm{v}}$} \\
\hline & Overall & $<0.0001$ & $<0.0001$ & $<0.0001$ & 0.0081 & 0.0157 & $<0.0001$ & 0.0053 & 0.0002 \\
\hline & Storage (S) & $<0.0001$ & $<0.0001$ & $<0.0001$ & 0.0088 & NS & $<0.0001$ & 0.0022 & $<0.0001$ \\
\hline & Harvest time $(\mathrm{H})$ & $<0.0001$ & NS & NS & NS & 0.0487 & 0.0291 & NS & NS \\
\hline & $\mathrm{S} \times \mathrm{H}$ & NS & NS & NS & Ns & 0.0198 & 0.0347 & NS & NS \\
\hline
\end{tabular}

${ }^{\mathrm{z}}$ Stems were harvested at three different times of the day $(0700 \mathrm{HR}$ to $0800 \mathrm{HR}, 1200 \mathrm{HR}$ to $1300 \mathrm{HR}$, or $1700 \mathrm{HR}$ to $1800 \mathrm{HR})$, placed in buckets containing tap water, transported to the laboratory within $1 \mathrm{~h}$ of harvest, sorted on the basis of stage of development and stem caliper, labeled, and either stored in the dark at $3 \pm 1{ }^{\circ} \mathrm{C}$ for 2 weeks in buckets containing tap water or placed in a postharvest evaluation laboratory in vases containing $300 \mathrm{~mL}$ tap water with three stems per vase. Data for fresh weight change represent means of five stems, water uptake represent means of five vases, whereas all other data represent means of 15 stems with three stems per vase.

${ }^{y}$ Final fresh weight minus initial fresh weight.

xercentage of stems exhibiting symptoms.

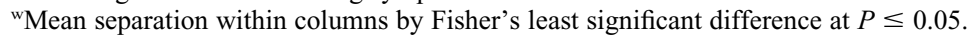

${ }^{\mathrm{v}} P$ values were obtained using General Linear Models procedures of SAS (Version 9.1; SAS Inst., Inc., Cary, NC).

NS $=$ Nonsignificant at $P>0.05$. 
Elite, Hitachi, Pleasanton, CA) using an isocratic gradient of distilled water with a flow rate of $0.4 \mathrm{~mL} \cdot \mathrm{min}^{-1}$ at 2688.9 to 2895.8 $\mathrm{kPa}$ (390 to $420 \mathrm{psi}$ ) back pressure and a BP$100 \mathrm{Ca}^{2+}$ carbohydrate guard column (Benson Polymeric Inc., Reno, NV). Individual carbohydrates were identified by comparison with standards and quantified by calculating a ratio of peak height of the unknown to the peak height of the sugar standard of known concentration (Locke, 2010). Data were subjected to analysis of variance procedures using General Linear Models procedures of SAS (Version 9.1; SAS Inst., Inc., Cary, NC) and means were separated by Fisher's least significant difference at $P \leq 0.05$.

\section{Results}

Lisianthus. Stems of lisianthus had longer vase life when harvested at noon or in the afternoon and stored for 2 weeks compared with morning-harvested stems treated similarly (Table 1). However, freshly harvested stems had similar vase life regardless of harvest time. On average, storage reduced vase life considerably from 10.8 to $5.6 \mathrm{~d}$. Harvest time and storage had no effects on fresh and dry weights at termination and fresh weight change, which averaged 9.0,2.1, and $2.7 \mathrm{~g}$, respectively.

Stems of lisianthus harvested in the afternoon had greater water uptake $(25.0 \mathrm{~mL})$ compared with morning- or noon-harvested stems, 20.2 and $19.4 \mathrm{~mL}$, respectively, when evaluated fresh (Table 1). Stored stems had similar but lower water uptake than afternoonharvested fresh stems. Stems harvested in afternoon and then stored for 2 weeks had a greater number of flowers opened during the vase period than morning- or noonharvested stems, whereas those evaluated fresh had similar number of opened flowers during the vase period (Table 1). Harvest time had no effect on vase water $\mathrm{pH}$ change; however, vase water of afternoon-harvested stems had a greater increase in EC than vase water of morning-harvested stems. Moreover, vase water of stored stems had a greater decrease in $\mathrm{pH}$ ( 0.3 units) than fresh stems (0.0 units), whereas vase water of freshly harvested stems had a greater increase in EC $\left(0.04 \mathrm{dS} \cdot \mathrm{m}^{-1}\right)$ compared with stored stems $\left(0.01 \mathrm{dS} \cdot \mathrm{m}^{-1}\right)$.

Stems harvested at noon had less petal fading compared with morning- or afternoonharvested stems (Table 1). Storage reduced petal wilting of stems harvested at noon and petal fading of stems harvested at noon or in the afternoon, although fresh stems had similar petal wilting and fading. Morning-harvested stems had less bent neck than noon- or afternoon-harvested stems when evaluated fresh. Fresh stems harvested late in the day had less leaf wilting compared with stored stems harvested at noon or morning.

Harvest time or storage for 2 weeks had no effect on LRWC (data not presented). Higher glucose and sucrose levels were present in stems harvested at noon or afternoon, whereas fructose was greater in stems harvested in the morning (Fig. 1). Substantial changes in the carbohydrate profile of the various tissues were observed over the first $7 \mathrm{~d}$ of vase life. Freshly harvested tissues had higher glucose, sucrose, and fructose levels, which decreased during storage and vase life except glucose in petals, which increased during vase life. During storage, a substantial decrease of glucose and sucrose in stems and leaves mirrored an increase of these sugars in petals. Among fresh stems sampled on Day 0 of vase life, petals of noon- or afternoonharvested stems had higher levels of glucose, and leaves and petals of noon-harvested stems had higher sucrose levels. However, on Day 7 of vase life, stem tissues of noon- or afternoon-harvested stems had higher sucrose levels. Fructose was lowest in noon- and afternoon-harvested petal tissues. In lisianthus, variations in sucrose levels were statistically significant among the various plant tissues (Table 2).

Marigold. In contrast to morning- or noon-harvested stems, those harvested in the afternoon had the longest vase life when evaluated fresh or after 2 weeks' storage (12.3 or $7.6 \mathrm{~d}$, respectively) (Table 3 ). Stems harvested at different times of the day had similar fresh weight change. Termination fresh weight, however, increased for the fresh stems but decreased for stored stems during vase life. All stems had similar termination dry weight irrespective of harvest time and storage and averaged $2.6 \mathrm{~g}$.

Fresh stems harvested in the morning had greater water uptake $(118.8 \mathrm{~mL})$ than afternoon- or noon-harvested stems (108.2 and $107.8 \mathrm{~mL}$, respectively; Table 3 ). Stored stems had similar water uptake regardless of the harvest time. Harvest time had no effect on $\mathrm{pH}$ change of vase water; however, vase water of noon- or afternoon-harvested stems had a greater increase in EC than vase water containing morning-harvested stems. Moreover, $\mathrm{pH}$ of vase water of the stored stems increased ( 0.1 units), whereas with fresh stems decreased ( 0.3 units). Vase water EC of stored stems had a greater increase $(0.23$ $\left.\mathrm{dS} \cdot \mathrm{m}^{-1}\right)$ compared with vase water of fresh stems $\left(0.13 \mathrm{dS} \cdot \mathrm{m}^{-1}\right)$.

Stems harvested at noon or in the afternoon and evaluated without storage had higher petal wilting and blackening (Table 3 ). Stored stems had similar petal wilting for all harvest times, whereas afternoonharvested stored stems had less petal blackening. Afternoon-harvested stems had turgid flower petals with less head collapse compared with morning- or noon-harvested stems, which further decreased with storage. Fresh stems had no bent neck, whereas storage increased bent neck in stems harvested in the morning compared with stems harvested at noon or in the afternoon. Adventitious roots developed at the basal ends of fresh stems during the vase period, irrespective of harvest time (Table 3). Stored stems had no roots even at the end of vase life.

Afternoon-harvested stems had the lowest LRWC when not stored (Table 4). In addition, during the first $7 \mathrm{~d}$ of vase life, LRWC greatly increased for unstored stems harvested in the morning and decreased for afternoon-harvested stems. Stems harvested at noon or in the afternoon had higher glucose, sucrose, and fructose concentrations compared with stems harvested in early morning (Fig. 2). Stems and leaves had higher sucrose, whereas glucose and fructose were higher in petals. During storage and/or the first $7 \mathrm{~d}$ of vase life, a considerable decrease in soluble sugars was observed in stems, presumably as a result of either depletion by metabolic activities or translocation to other tissues.

Table 4. Effect of storage duration and harvest time on leaf relative water contents (\%) of 'Double Eagle' African Gold Coin Series marigold and 'Deep Red' Benary's Giant Series zinnia. ${ }^{\text {' }}$

\begin{tabular}{|c|c|c|c|c|c|c|c|}
\hline \multicolumn{2}{|c|}{ Treatments } & \multicolumn{3}{|c|}{ Marigold } & \multicolumn{3}{|c|}{ Zinnia } \\
\hline $\begin{array}{l}\text { Storage duration } \\
\text { (weeks) }\end{array}$ & Harvest time & Day 0 & Day 7 & Change & Day 0 & Day 7 & Change \\
\hline \multirow[t]{3}{*}{$\overline{0}$} & $0700 \mathrm{HR}$ to $0800 \mathrm{HR}$ & 81.7 & $94.4 \mathrm{a}^{\mathrm{y}}$ & 12.7 & $67.6 \mathrm{ab}$ & 71.5 & 3.8 \\
\hline & $1200 \mathrm{HR}$ to $1300 \mathrm{HR}$ & 75.3 & $76.6 \mathrm{ab}$ & 1.3 & $58.8 \mathrm{~b}$ & 57.7 & -1.1 \\
\hline & $1700 \mathrm{HR}$ to $1800 \mathrm{HR}$ & 70.0 & $55.2 \mathrm{~b}$ & -15.1 & $75.2 \mathrm{ab}$ & 54.7 & -20.6 \\
\hline \multirow[t]{3}{*}{2} & $0700 \mathrm{HR}$ to $0800 \mathrm{HR}$ & 78.2 & $78.2 \mathrm{ab}$ & 0.0 & $94.5 \mathrm{a}$ & $-{ }^{x}$ & - \\
\hline & $1200 \mathrm{HR}$ to $1300 \mathrm{HR}$ & 78.7 & $82.2 \mathrm{ab}$ & 3.6 & $75.0 \mathrm{ab}$ & - & - \\
\hline & $1700 \mathrm{HR}$ to $1800 \mathrm{HR}$ & 90.5 & $87.5 \mathrm{a}$ & -7.1 & $81.1 \mathrm{ab}$ & - & - \\
\hline \multicolumn{8}{|l|}{ Significance $^{w}$} \\
\hline & Overall & NS & 0.0127 & NS & 0.0109 & NS & NS \\
\hline & Storage (S) & NS & NS & NS & 0.0037 & - & - \\
\hline & Harvest time $(\mathrm{H})$ & NS & NS & NS & NS & NS & NS \\
\hline & $\mathrm{S} \times \mathrm{H}$ & NS & 0.0153 & NS & NS & - & - \\
\hline
\end{tabular}

${ }^{\mathrm{z}}$ Stems were harvested at three different times of the day $(0700 \mathrm{HR}$ to $0800 \mathrm{HR}, 1200 \mathrm{HR}$ to $1300 \mathrm{HR}$, or 1700 HR to $1800 \mathrm{HR}$ ), placed in buckets containing tap water, transported to the laboratory within $1 \mathrm{~h}$ of harvest, sorted on the basis of stage of development and stem caliper, labeled, and either stored in the dark at $3 \pm 1$ ${ }^{\circ} \mathrm{C}$ for 2 weeks in buckets containing tap water or placed in a postharvest evaluation laboratory in vases containing $300 \mathrm{~mL}$ tap water with three stems per vase. Data represent means of five stems.

'Mean separation within columns by Fisher's least significant difference at $P \leq 0.05$.

${ }^{\mathrm{x}}$ Stems died before data collection.

${ }^{\text {w }} P$ values were obtained using General Linear Models procedures of SAS (Version 9.1; SAS Inst., Inc., Cary, NC).

NS $=$ Nonsignificant at $P>0.05$. 




Day 0

Day 7

Fig. 2. Effect of daily harvest time ( $0700 \mathrm{HR}$ to $0800 \mathrm{HR}, 1200 \mathrm{HR}$ to $1300 \mathrm{HR}$, or $1700 \mathrm{HR}$ to $1800 \mathrm{HR}$ ), storage duration (no storage or 2 weeks), and day of sampling after beginning of vase life determination (Day 0 or 7 ) on glucose (A-B), sucrose (C-D), and fructose (E-F) levels in stem, leaf, and petal tissues of 'Double Eagle' marigold. Each bar is a mean of three observations. A bar without an asterisk indicates nonsignificant and *,**, or *** indicate significant at $P \leq 0.05$, 0.01 , or 0.001 , respectively.

Flower petals of stored stems had higher sugar levels than stems or leaves. Petals of stems harvested at noon or afternoon had greater glucose, sucrose, and fructose than petals of morning harvests. Moreover, leaves of noon-harvested stems had higher sucrose concentration on Day 0 of vase life. Petals of marigold had significantly higher glucose, sucrose, and fructose and overall, all sugars were significantly variable among stem, leaf, and petal tissues (Table 2).

Zinnia. Time of harvest had no effect on vase life of zinnia, whereas storage greatly reduced longevity (Table 5). Fresh stems harvested in the afternoon had smaller fresh weight change compared with morning-harvested stems. Stored stems had similar fresh weight change. Harvest time and storage had no effect on dry weight of stems, which averaged $2.2 \mathrm{~g}$.

Stems harvested in the afternoon had higher water uptake compared with stems harvested in 
Table 5. Effect of storage duration and harvest time on vase life, fresh weight change, water uptake, and termination symptoms (petal fading, petal blackening, or stem collapse) of 'Deep Red' Benary's Giant Series zinnia. ${ }^{2}$

\begin{tabular}{|c|c|c|c|c|c|c|c|}
\hline \multicolumn{2}{|c|}{ Treatments } & \multirow[b]{2}{*}{$\begin{array}{l}\text { Vase } \\
\text { life }(d)\end{array}$} & \multirow[b]{2}{*}{$\begin{array}{l}\text { Fresh wt } \\
\text { change }^{y}(g)\end{array}$} & \multirow[b]{2}{*}{$\begin{array}{c}\text { Water } \\
\text { uptake }(\mathrm{mL})\end{array}$} & \multicolumn{3}{|c|}{ Termination symptoms $^{\mathrm{x}}$} \\
\hline $\begin{array}{l}\text { Storage duration } \\
\text { (weeks) }\end{array}$ & Harvest time & & & & $\begin{array}{c}\text { Petal } \\
\text { fading }(\%)\end{array}$ & $\begin{array}{c}\text { Petal } \\
\text { blackening }(\%)\end{array}$ & $\begin{array}{c}\text { Stem } \\
\text { collapse (\%) }\end{array}$ \\
\hline 0 & $0700 \mathrm{HR}$ to $0800 \mathrm{HR}$ & $14.7 \mathrm{a}^{\mathrm{w}}$ & $-3.2 \mathrm{ab}$ & $135.4 \mathrm{~b}$ & $87 \mathrm{a}$ & $53 \mathrm{~b}$ & $27 \mathrm{bc}$ \\
\hline \multirow[t]{2}{*}{2} & $0700 \mathrm{HR}$ to $0800 \mathrm{HR}$ & $1.3 \mathrm{~b}$ & $-4.1 b$ & $19.4 \mathrm{~d}$ & $93 \mathrm{a}$ & $93 \mathrm{a}$ & $33 \mathrm{bc}$ \\
\hline & $1200 \mathrm{HR}$ to $1300 \mathrm{HR}$ & $0.9 \mathrm{~b}$ & $-3.0 \mathrm{ab}$ & $35.2 \mathrm{~cd}$ & $47 \mathrm{~b}$ & $93 \mathrm{a}$ & $67 \mathrm{a}$ \\
\hline \multicolumn{8}{|l|}{ Significance $^{\mathrm{v}}$} \\
\hline & Overall & $<0.0001$ & NS & $<0.0001$ & 0.0133 & 0.0029 & 0.0019 \\
\hline & Storage (S) & $<0.0001$ & 0.0399 & $<0.0001$ & NS & $<0.0001$ & 0.0002 \\
\hline & Harvest time $(\mathrm{H})$ & NS & NS & 0.0001 & NS & NS & NS \\
\hline & $\mathrm{S} \times \mathrm{H}$ & NS & NS & NS & 0.0115 & NS & NS \\
\hline
\end{tabular}

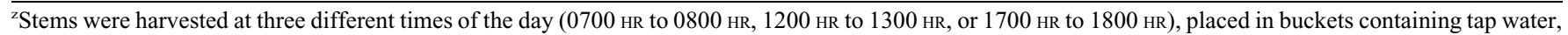

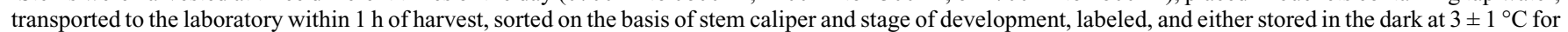

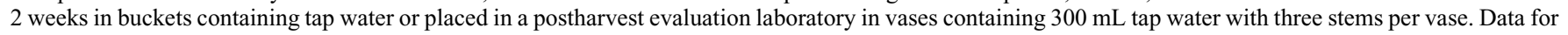

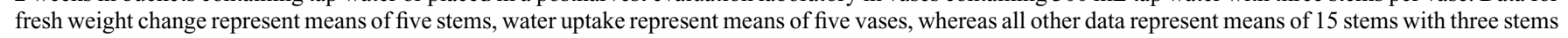
per vase.

${ }^{\mathrm{y}}$ Final fresh weight minus initial fresh weight.

xPercentage of stems exhibiting symptoms.

wMean separation within columns by Fisher's least significant difference at $P \leq 0.05$.

${ }^{\vee} P$ values were obtained using General Linear Models procedures of SAS (Version 9.1; SAS Inst., Inc., Cary, NC).

NS $=$ Nonsignificant at $P>0.05$.

the morning or noon (Table 5). A similar trend in uptake was observed for fresh and stored stems. Vase water of stems harvested at noon or in the afternoon had a greater increase (fresh stems) or decrease (stored stems) in $\mathrm{pH}$ and greater increase in vase water EC change than water having morningharvested stems. Moreover, $\mathrm{pH}$ of vase water of the fresh stems increased (0.7 units), whereas that of stored stems decreased $(0.3$ units). Vase water containing fresh stems had a greater increase in EC $\left(0.07 \mathrm{dS} \cdot \mathrm{m}^{-1}\right)$ than vase water containing stored stems $\left(0.02 \mathrm{dS} \cdot \mathrm{m}^{-1}\right)$.

For freshly harvested stems (without storage), stems harvested in the afternoon had less petal fading and stem collapse than stems harvested in the morning (Table 5). Storage increased stem collapse and petal blackening, but no differences were observed for petal blackening between different times of harvest. Similar petal wilting and drying were observed for all treatments, which averaged $86 \%$ and $77 \%$, respectively.

Fresh stems harvested at noon had lower LRWC compared with stored stems harvested in the morning (Table 4). Moreover, during the first $7 \mathrm{~d}$ of vase life, LRWC of the afternoon-harvested stems decreased greatly compared with noon- or morning-harvested stems. Stems harvested in the morning and stored also tended to have higher LRWC at Day 0. Zinnia did not tolerate cold storage; therefore, no clear pattern was observed for carbohydrate levels of stems harvested at different times of the day. Among tissues, petals had higher glucose and fructose, whereas sucrose was higher in the stems or leaves (Fig. 3). Fresh stems had lower glucose in the flower petals of afternoon-harvested stems. Sucrose was greater in afternoon-harvested stem tissues at Day 0 or 7 of vase life. Fructose levels were similar in all tissues except leaves of stems harvested in the afternoon and stored.
No differences were observed in any soluble sugar on Day 7 of vase life. However, total carbohydrates were significantly variable in different tissues (Table 2). Petals had greater levels of sucrose, glucose, and fructose.

\section{Discussion}

Commercial cut flower growers harvest flowers early in the morning to process the stems the same day and to avoid exposure to field heat, which reduces quality. However, postharvest performance of cut lisianthus and marigold can be increased substantially by harvesting later in the day. Harvest time during the day not only affected cut flower longevity, but also water relations and carbohydrate status of cut lisianthus and marigold. The key finding of the present study was correlation of postharvest longevity of lisianthus and marigold with the harvest time of the day. Fresh stems of lisianthus and marigold harvested later in the day had $105 \%$ and $130 \%$ longer vase life, whereas stored stems had $154 \%$ and $181 \%$ longer vase life, respectively, compared with early morning harvested stems (Tables 1 and 3). Greater vase life extension was associated with higher carbohydrate accumulation in the stems during the day. These findings can assist cut flower growers to extend vase life by rescheduling the time stems are harvested during the day. Similar improvements in shelf life of sweet basil (Lange and Cameron, 1994), baby salad (Clarkson et al., 2005), broccoli (Hasperué et al., 2011), and unrooted shoot-tip cuttings of lantana (Rapaka et al., 2007) were observed when harvested later in the day.

Harvest time of day had no effect on termination fresh and dry weights and fresh weight changes in any of the three tested species (Tables 3 and 5; lisianthus data not presented). Stems of lisianthus and zinnia had higher water uptake for afternoon harvests, whereas marigold stems harvested in early morning had higher water uptake (Tables 1 , 3 , and 5). For all species, fresh stems had higher water uptake than stored stems. The higher water uptake of lisianthus and zinnia compared with marigold might be the result of larger leaf and petal area with a greater number of stomata increasing transpiration.

The smaller variation in EC for stored stems of lisianthus and zinnia as compared with unstored stems may have been the result of the considerably shorter vase life of stored stems. Moreover, deterioration of marigold stem tissues maintained in water during storage and during the vase period may also have increased $\mathrm{pH}$ and $\mathrm{EC}$ of the vase solutions.

Petal fading, wilting, or necrosis; stem bent neck; or leaf wilting were common symptoms of senescence in the three species tested. The studies involving marigold and zinnia were repeated and the results were similar to those reported here. Stems of lisianthus harvested at noon or in the afternoon had comparatively less petal fading and leaf wilting and at the same times of harvest, there was less petal drop and head collapse in marigold. All these findings suggest a role for carbohydrates in slowing senescence in afternoon-harvested stems compared with those harvested in early morning. Moreover, storage reduced carbohydrate levels, which may explain why adventitious rooting of marigold stems did not occur during the subsequent vase period.

Leaf water relations are hypothesized to follow a diurnal pattern controlled by stomatal opening in response to photoperiod and temperature (Taylor and Davies, 1985). These relations can increase turgor pressure near the end of the photoperiod, which could also contribute to vase life extension of the cut stems. In the present study, fresh stems of zinnia 


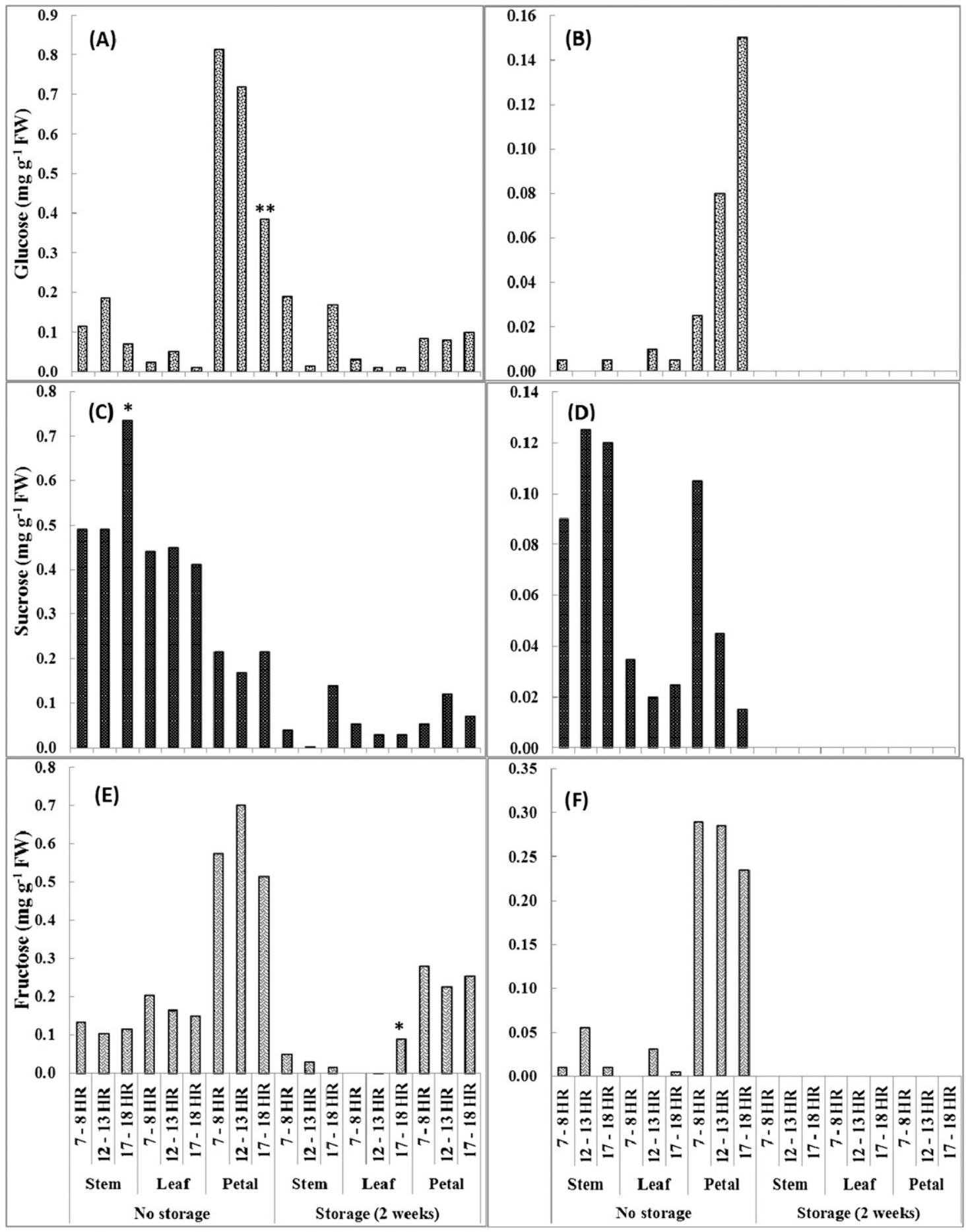

Day 0

Day 7

Fig. 3. Effect of daily harvest time ( $0700 \mathrm{HR}$ to $0800 \mathrm{HR}, 1200 \mathrm{HR}$ to $1300 \mathrm{HR}$, or $1700 \mathrm{HR}$ to $1800 \mathrm{HR}$ ), storage duration (no storage or 2 weeks), and day of sampling after beginning of vase life determination (Day 0 or 7) on glucose (A-B), sucrose (C-D), and fructose (E-F) levels in stem, leaf, and petal tissues of 'Deep Red' zinnia. Each bar is a mean of three observations. A bar without an asterisk indicates nonsignificant and * or ** indicates significant at $P \leq 0.05$ or 0.01 , respectively.

harvested at noon had lower LRWC than stored stems harvested in the morning (Table 4). For marigold, afternoon-harvested stems had the lowest LRWC on Day 7 of vase life when not stored. In addition, during the first $7 \mathrm{~d}$ of marigold vase life, LRWC greatly increased for unstored stems harvested in the morning and decreased for afternoonharvested stems. This might be the result of water use during photosynthesis throughout the light period (Clarkson et al., 2005). King et al. (1982) reported leaf water relations affected chilling sensitivity of tomato seedlings in early morning. For lisianthus,
LRWC was not influenced by harvest time or storage.

Photosynthesis replenishes sugars metabolized or mobilized during the dark period. In the present study, a diurnal pattern of sugar accumulation was observed with greater amounts of sugars (particularly glucose and 
sucrose) accumulating during the day as a result of photosynthesis (Forney and Austin, 1988; Sicher et al., 1984). Afternoon-harvested stems of marigold and zinnia had higher sucrose levels, whereas stems of lisianthus had higher levels of sucrose at noon than morning-harvested stems. Increased sugar concentrations in afternoon-harvested produce not only protects against harvest stress, but also against chilling injury as observed in seedlings of tomato (King et al., 1988). Among tissues, petals initially had higher glucose, which increased further during vase life, presumably as a result of translocation from stem and leaves (Table 2; Figs. 1, 2, and 3). Sucrose was higher in stems and leaves, whereas fructose was greater in petals followed by leaves. During storage, a considerable decrease in glucose and sucrose was observed, likely as a result of metabolism or conversion to other sugars, whereas fructose levels were comparatively stable. Sucrose levels increased from morning to noon in leaves of all tested species but then decreased for afternoon-harvested stems. A similar response has also been reported by Rapaka et al. (2007) for shoot-tip cuttings of lantana and leaves of sugar beet (Beta vulgaris L.) by Fondy and Geiger (1982). Fructose levels of all three species were higher in morningharvested stem tissues and noon- or afternoonharvested leaves and petals immediately after harvest, which was mobilized to petals during storage. Considerable decreases in fructose were detected during the first $7 \mathrm{~d}$ of vase life, presumably being consumed by metabolism. Considering all the results, stems harvested later in the day had overall higher accumulation of carbohydrates, particularly sucrose, than morning-harvested stems as a result of exposure to light, which delayed senescence. These findings corroborate the effect of carbohydrates on delaying postharvest senescence of cut stems of marigold and lisianthus and also broccoli as reported by Irving and Joyce (1995). Conversely, zinnia harvested at different times of the day did not show differences in vase life. Statistically similar sugar levels were found for tissue samples of zinnia harvested at different times of the day and analyzed immediately after harvest. Klieber et al. (2002) have also reported similar results for Chinese cabbage (Brassica oleracea var. capitata L.) harvested at different times of the day. Data here indicate differences in species sensitivity to harvest time of the day with marigold exhibiting the greatest benefit from afternoon harvest followed by lisianthus.

\section{Conclusions}

This investigation demonstrated the potential impact of time of the day at harvest on postharvest longevity of cut lisianthus and marigold. No effect was observed in zinnia. Harvesting stems later in the day (1700 HR to $1800 \mathrm{HR}$ ) delayed postharvest senescence of cut marigold and lisianthus, but not zinnia, compared with morning-harvested stems. These results suggest growers may consider rescheduling the daily time of harvest of particular cut flowers for significant extension of postharvest longevity. Results here indicate that an afternoon harvest is necessary for extending vase life of some species like marigold and lisianthus. Moreover, the specific responses of particular species to harvest time of the day as reported here highlight the need to evaluate the phenomenon in other species and cultivars.

\section{Literature Cited}

Ahmad, I., J.M. Dole, A. Amjad, and S. Ahmad. 2012. Dry storage effects on postharvest performance of selected cut flowers. HortTechnology 22:463-469.

Argyroudi-Akoyunoglou, J.H. and A. Prombona. 1996. Light-independent endogenous circadian rhythm in the capacity for chlorophyll formation. J. Photochem. Photobiol. B 36:271-277.

Blankenship, S.M. and J.M. Dole. 2003. 1-Methylcyclopropene: A review. Postharvest Biol. Technol. 28:1-25.

Celikel, F.G. and M.S. Reid. 2002. Storage temperature affects the quality of cut flowers from the Asteraceae. HortScience 37:148-150.

Chamani, E., A. Khalighi, D.C. Joyce, D.E. Irving, Z.A. Zamani, Y. Mostofi, and M. Kafi. 2005. Ethylene and anti-ethylene treatment effects on cut 'First Red' rose. J. Appl. Hort. 7:3-7.

Chuang, Y. and Y.A. Chang. 2013. The role of soluble sugars in vase solutions during the vase life of Eustoma grandiflorum. HortScience 48:222-226.

Clarkson, G.J.J., S.D. Rothwell, and G. Taylor. 2005. End of day harvest extends shelf life. HortScience 40:1431-1435.

Doi, M. and M.S. Reid. 1995. Sucrose improves the postharvest life of cut flowers of a hybrid Limonium. HortScience 30:1058-1060.

Elhindi, K.M. 2012. Effects of postharvest pretreatments and preservative solutions on vase life longevity and flower quality of sweet pea (Lathyrus odoratus L.). Photosynthetica 50:371-379.

Fondy, B.R. and D.R. Geiger. 1982. Diurnal pattern of translocation and carbohydrate metabolism in source leaves of Beta vulgaris $\mathrm{L}$. Plant Physiol. 70:671-676.

Forney, C.F. and R.K. Austin. 1988. Time of day at harvest influences carbohydrate concentration in crisphead lettuce and its sensitivity to high $\mathrm{CO}_{2}$ levels after harvest. J. Amer. Soc. Hort. Sci. 113:581-583.

Gast, K.L.B. 1997. Postharvest handling of fresh cut flowers and plant material. Kansas State Agr. Expt. Sta. Coop. Ext. Serv. Publ. MF-2261.

Halevy, A.H. and S. Mayak. 1979. Senescence and postharvest physiology of cut flowers-Part $1, p$. 204-236. In: Jancik, J. (ed.). Horticultural reviews. Vol. 1. AVI Publishing Co., Inc., Westport, CT.

Halevy, A.H. and S. Mayak. 1981. Senescence and postharvest physiology of cut flowers-Part 2, $\mathrm{p}$. 59-143. In: Jancik, J. (ed.). Horticultural reviews. Vol. 3. AVI Publishing Co., Inc., Westport, CT.

Hasperué, J.H., A.R. Chaves, and G.A. Martínez. 2011. End of day harvest delays postharvest senescence of broccoli florets. Postharvest Biol. Technol. 59:64-70.

Irving, D.D. and D.C. Joyce. 1995. Sucrose supply can increase longevity of broccoli (Brassica oleracea) branchlets kept at $22^{\circ} \mathrm{C}$. Plant Growth Regulat. 17:251-256.

Jones, M.L., K.K. Cochran, G.A. Anderson, and D.C. Ferree. 2004. Effects of preservatives and cold storage on postharvest performance of deciduous holly branches. HortTechnology $14: 230-234$
Kim, J.H., A.K. Lee, and J.K. Suh. 2005. Effect of certain pre-treatment substances on vase life and physiological characters in Lilium spp. Acta Hort. 673:307-314.

King, A.I., D.C. Joyce, and M.S. Reid. 1988. Role of carbohydrate in diurnal chilling sensitivity of tomato seedlings. Plant Physiol. 86:764-768.

King, A.I., M.S. Reid, and B.D. Patterson. 1982. Diurnal changes in the chilling sensitivity of seedlings. Plant Physiol. 70:211-214.

Kiyota, M., N. Numayama, and K. Goto. 2006. Circadian rhythms of the L-ascorbic acid level in Euglena and spinach. J. Photochem. Photobiol. B 84:197-203.

Klieber, A., K.L. Porter, and G. Collins. 2002. Harvesting at different times of day does not influence the postharvest life of Chinese cabbage. Sci. Hort. 96:1-9.

Lange, D.D. and A.C. Cameron. 1994. Postharvest shelf life of sweet basil (Ocimum basilicum). HortScience 29:102-103.

Liu, J., K. Ratnayake, D.C. Joyce, S. He, and Z. Zhang. 2012. Effects of three different nanosilver formulations on cut Acacia holosericea vase life. Postharvest Biol. Technol. 66:8-15.

Locke, E.L. 2010. Extending cut flower vase life by optimizing carbohydrate status: Preharvest conditions and preservative solution. $\mathrm{PhD}$ diss., NC State Univ., Raleigh, NC.

Marissen, N. and J. Benninga. 2001. Nursery comparison on the vase life of the rose 'First Red': Effects of growth circumstances. Acta Hort. 543:285-291.

Moccia, S., D. Frezza, and A. Chiesa. 1998. Time of day at harvest effect on postharvest lettuce quality. Agri. Trop. et Subtrop. 31:83-86.

Nishikawa, F., T. Iwama, M. Kato, H. Hyodo, Y. Ikoma, and M. Yano. 2005. Effect of sugars on ethylene synthesis and responsiveness in harvested broccoli florets. Postharvest Biol. Technol. 36:157-165.

Rapaka, V.K., J.E. Faust, J.M. Dole, and E.S. Runkle. 2007. Effect of time of harvest on postharvest leaf abscission in lantana (Lantana camara L. 'Dallas Red') unrooted cuttings. HortScience 42:304-308.

Reid, M.S. and C. Jiang. 2012. Postharvest biology and technology of cut flowers and potted plants, p. 1-54. In: Jancik, J. (ed.). Horticultural reviews. Vol. 40. Wiley-Blackwell, NJ.

Sacalis, J.N. 1993. Cut flowers: Prolonging freshness, post production care and handling. 2nd Ed. In: Seals, J.L. (ed.). Ball Publishing, Batavia, IL. p. 52-54.

Sicher, R.C., D.F. Kremer, and W.G. Harris. 1984. Diurnal carbohydrate metabolism of barley primary leaves. Plant Physiol. 76:165-169.

Slootweg, G. 2005. Effects of greenhouse conditions on the quality and vase life of Freesia 'Yvonne'. A nursery comparison. Acta Hort. 669:297-301.

Smart, R.E. and G.E. Bingham. 1974. Rapid estimates of relative water content. Plant Physiol. 5:58-60.

Staby, G.L., R.M. Basel, M.S. Reid, and L.L. Dodge. 1993. Efficacies of commercial antiethylene products for fresh cut flowers. HortTechnology 3:199-202.

Taylor, G. and W.J. Davies. 1985. The control of leaf growth of Betula and Acer by photoenvironment. New Phytol. 101:259-268.

van Doorn, W.G. 2012. Water relations of cut flowers: An update, p. 55-106. In: Janick, J. (ed.). Horticultural reviews. Vol. 40. Wiley-Blackwell, NJ.

Verlinden, S. and J.J.V. Garcia. 2004. Sucrose loading decreases ethylene responsiveness in carnation (Dianthus caryophyllus cv. White Sim) petals. Postharvest Biol. Technol. 31: 305-312. 